\title{
Prostatic Carcinosarcoma: A Case Report
}

\section{Prostat Karsinosarkomu: Olgu Sunumu}

\author{
Yusuf Şenoğlu MD1, Kamil Çam MD2, Havva Erdem MD³, Muhammet Ali Kayıkçı MD4, Ali Tekin MD4 \\ 'Aliağa State Hospital, Clinic of Urology, Izmir, Turkey \\ 2Marmara University, Pendik Training and Research Hospital, Clinic of Urology, Istanbul, Turkey \\ ${ }^{3}$ Düzce University Faculty of Medicine, Department of Pathology, Düzce, Turkey \\ 4 Düzce University Faculty of Medicine, Department of Urology, Düzce, Turkey
}

\begin{abstract}
Prostatic carcinosarcoma is a rare malignancy composed of sarcomatous and carcinomatous elements. Predominantly, they are very aggressive tumors with a poor prognosis. In this case report, a 78 year-old male patient with prostate adenocarcinoma developing prostatic carcinosarcoma after using androgen blockade for 3 years was presented. We tried to define the clinical and pathological features of this rare malignancy with current information.
\end{abstract}

Keywords: Prostate, carcinosarcoma, adenocarcinoma
Öz

Prostat karsinosarkomu, sarkomatöz ve karsinomatöz unsurlardan oluşan nadir bir malignitedir. Sıklıkla kötü prognozu olan çok agresif tümörlerdir. Bu olgu sunumunda, 3 yıl maksimum androjen blokajı alan prostat adenokarsinomu olgusunda prostat karsinosarkomu gelişen 78 yaşındaki bir erkek hasta sunuldu. Bu nadir görülen malignitenin klinik ve patolojik özelliklerini güncel bilgilerle tanımlamaya çalıştık.

Anahtar Kelimeler: Prostat, karsinosarkom, adenokarsinom

\section{Introduction}

Prostate carcinosarcoma is extremely rare and aggressive neoplasm. It constitutes approximately $0.1 \%$ of all neoplasias of prostate, and mostly seen in $6^{\text {th }}$ and $7^{\text {th }}$ decades (1). As its name denotes, it contains sarcomatoid and malign epithelial components (2). Epithelial component exhibits different Gleason patterns and prostate-specific antigen (PSA) staining is positive. Sarcomatous component is usually composed of nonspecific spindle cells. Heterologous differentiation can be observed with chondrosarcoma, osteosarcoma, leiomyosarcoma, rhabdomyosarcoma, liposarcoma or any combinations thereof (2). Serum PSA levels are usually within normal limits (3). Prostate adenocarcinoma previously seen in $50 \%$ of cases. Carcinosarcoma can develop secondary to hormonal therapy and radiotherapies (4). Lung and liver metastases are common. Nowadays, a small number of prostate carcinosarcoma cases have been reported in the literature (5). Therefore, there is no standard treatment protocol. Here, we defined a 78-year old carcinosarcoma developed at $3^{\text {rd }}$ year of hormonal treatment.

\section{Case Presentation}

A 78 year-old man with prostate adenocarcinoma referred to our department with lower urinary tract symptoms and macroscopic hematuria. The patient was diagnosed with prostate adenocarcinoma 3 years ago. The serum PSA level was $65 \mathrm{ng} / \mathrm{mL}$, the initial prostate biopsy revealed prostate adenocarcoma of Gleason 4+3. No report was available regarding metastatic evaluation. Combined androgen blockade with goserelin and bicalutamide was started three years ago.

The patient had urethral catheter for 2 months. The last serum PSA level was $1.21 \mathrm{ng} / \mathrm{mL}$. On digital rectal exam, a stony hard prostate fixed to the surrounding tissue was palpated. Cystoscopy revealed a gross hematoma in the bladder without any lesion. The patient underwent transurethral prostate resection and bilateral orchiectomy. No metastasis was detected on thoracic and abdominal computed tomography. Histopathological examination revealed carcinosarcoma of prostate. Histologically, the tumor was found to consist of a mixture of bizarre like cells; atypical, pleomorphic spindle cells with many atypical mitosis and some areas of osteoid-like appearance (Figure 1). Epithelial component was found in a small area. Epithelial cells were positive for cytokeratin panantibody whereas the other areas were negative. Sarcomatous components were stained positive for vimentin, CD68, smooth muscle actin; negative for CD34, S100, PSA, desmin (Figure 2). The patient was discharged from our hospital with urethral catheter due to a lack of urination spontaneously. There was 
no further hematuria. Radical extensive prostatectomy was discussed with patient, but he refused any surgery or systemic treatment. The overall situation has deteriorated in the followup and the patient died 5 months later.

\section{Discussion}

Carcinosarcoma of the prostate was first reported in the early 1970 s. On the formation of prostate carcinosarcoma there were 5 theories; 1 ) incidental carcinoma and sarcoma development in separate areas of the prostate 2) two-way differentiation of immature stem cells 3 ) transformation from adenocarcinoma into sarcoma 4) transformation from sarcoma into adenocarcinoma 5) tumor differentiation due to radiotherapy and hormonal therapy effects (4). In our case, sarcomatous component was not detected at the first biopsy. Carcinosarcoma were diagnosed with transurethral prostatectomy after 3 years of hormonal therapy. Some studies focus on radiotherapy and hormonal therapy that may lead to transformation of carcinosarcoma (6). Approximately $50 \%$ of carcinosarcoma cases, the first

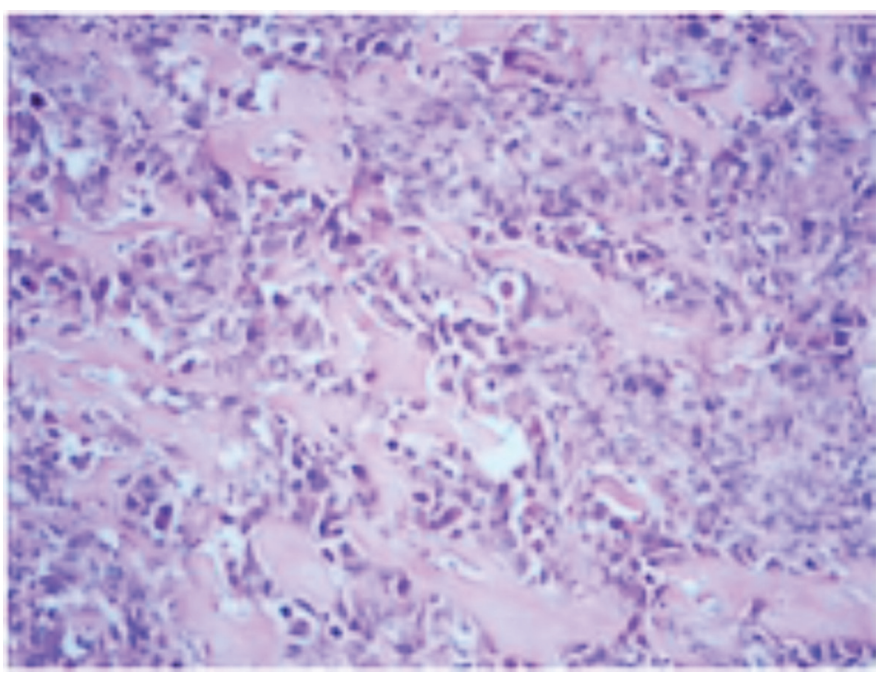

Figure 1. Characteristic features of carcinosarcoma: Osteoid like material

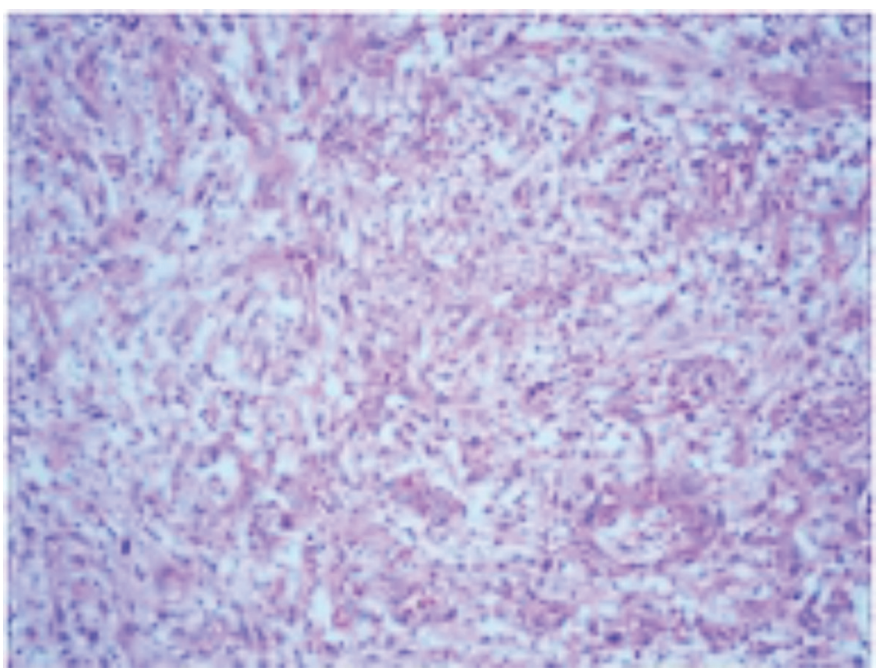

Figure 2. Characteristic features of carcinosarcoma: Spindle bizarre cells biopsies are acinar adenocarcinoma. It was demonstrated the time for carcinosarcoma development from adenocarcinoma is approximately 3 years as seen in our case $(7,8)$. However, histogenesis has not been fully elucidated (9).

PSA levels are usually within normal range in sarcomas of prostate. Sarcomatous tumor cells are undifferentiated and have no capacity to raise serum PSA levels. Therefore, only a small number of patients have an elevated serum PSA level (10). Our patient had also normal PSA values. This finding suggests that routine digital rectal examination of the prostate should not be ignored in patients under hormonal treatment with normal PSA values.

When the sarcomatoid carcinoma diagnosed, in about $25 \%$ of cases have metastasis. Dundore et al. (11) report that the lung was the most frequent site for metastases except lymph nodes. It has remained respectively in the bone and brain. We did not detect metastasis in our case.

According to Weiss and Enzinger et al. (12); radiation therapy, antiandrogen therapy, histologic subtype, necrosis rate, grade of sarcoma are not predictive to estimate overall survival. Only negative surgical margins and the absence of metastasis have a positive effect on survival. If the carcinosarcoma spreads to the whole prostate tissue survival is reported to be about 6 months (13). Radiotherapy, surgery, hormonal therapy or chemotherapy were used in the treatment but the results of treatment were not satisfactory. The survival was found to be 7 months and there were no predictive parameters to detect it (14). In our case, carcinosarcoma was common in the tissue; and even no metastases was seen, the survival was about 5 months.

In conclusion, prostate carcinosarcoma is a very rare and aggressive cancer. There are no standard treatment recommendations for the management of carcinosarcoma of prostate. It should be diagnosed at the stage the surgical treatment is possible. Large-scale researches in the future will be better to recognize the carcinosarcoma and shed light on the most appropriate treatment method. Moreover, since mostly serum PSA levels are normal, digital rectal examination may be the only tool that can provide early diagnosis for prostate carcinosarcoma in patients under hormonal treatment.

\section{Ethics}

Informed Consent: Consent form was filled out by the participant.

Peer-review: Externally peer-reviewed.

\section{Authorship Contributions}

Surgical and Medical Practices: Y.Ş., K.Ç., Concept: Y.Ş., K.Ç., M.A.K., Design: Y.Ş., K.Ç., M.A.K., Data Collection or Processing: Y.Ş., H.E., Analysis or Interpretation: Y.Ş., K.Ç., A.T., Literature Search: Y.Ş., Writing: Y.Ş., K.Ç.

Conflict of Interest: No conflict of interest was declared by the authors.

Financial Disclosure: The authors declared that this study received no financial support.

\section{References}

1. Quay SC, Proppe KH. Carcinosarcoma of the prostate: case report and review of the literature. J Urol 1981;125:436-438. 
2. Somarelli JA, Boss MK, Epstein JI, et al. Carcinosarcomas: tumors in transition? Histol Histopathol 2015;30:673-687.

3. Rogers CG, Parwani A, Tekes A, et al. Carcinosarcoma of the prostate with urothelial and squamous components. J Urol 2005; 173:439-440.

4. Lauwers GY, Schevchuk M, Armenakas N, Reuter VE. Carcinosarcoma of the prostate. Am J Surg Pathol 1993;17:342-349.

5. Nazeer T, Barada JH, Fisher HA, Ross JS. Prostatic carcinosarcoma: case report and review of literature. J Urol 1991;146:1370-1373.

6. Hansel DE, Epstein JI. Sarcomatoid carcinoma of the prostate: a study of 42 cases. Am J Surg Pathol 2006;30:1316-1321.

7. Ray ME, Wojno KJ, Goldstein KJ, et al. Clonality of sarcomatous and carcinomatous elements in sarcomatoid carcinoma of the prostate. Urology 2006;67:423e5-423e8.

8. Delahunt B, Eble JN, Nacey JN, Grebe SK. Sarcomatoid carcinoma of the prostate: progression from adenocarcinoma associated with p53 over-expression. Anticancer Res 1999;19:4279-4283.

9. Orsatti G, Corgan FJ, Goldberg SA. Carcinosarcoma of urothelial organs: sequential involvement of urinary bladder, ureter, and renal pelvis. Urology 1993;41:289-291.

10. Krastanova LJ, Addonizio JC. Carcinosarcoma of prostate. Urology 1981;18:85-88.

11. Dundore PA, Cheville JC, Nascimento AG, et al. Carcinosarcoma of the prostate. Report of 21 cases. Cancer 1995;76:1035-1042.

12. Weiss SW, Enzinger FM. Malignant fibrous histiocytoma: an analysis of 200 cases. Cancer 1978;41:2250-2266.

13. Koleski FC, Turk TM, Wojcik EM, Albala DM. Carcinosarcoma of the prostate. World J Urol 1999;17:316-318.

14. Fukawa T, Numata K, Yamanaka M, et al. Prostatic carcinosarcoma: a case report and review of literature. Int J Urol 2003;10:108-113. 